Published in final edited form as:

Am J Trop Med Hyg. 2009 April ; 80(4): 508-515.

\title{
Placental Malaria and Mother-to-Child Transmission of Human Immunodeficiency Virus-1
}

\author{
Gernard I. Msamanga*, \\ Department of Community Health, Muhimbili University College of Health Sciences, United \\ Nations Road, PO Box 65001, Dar es Salaam, Tanzania, gmsamanga@muhas.ac.tz.
}

\section{Taha E. Taha,}

Johns Hopkins University Bloomberg School of Hygiene and Public Health, 615 North Wolfe Street, Room E 6011, Baltimore, MD 21205, ttaha@jhsph.edu.

\section{Alicia M. Young, \\ Statistical Center for HIV/AIDS Research and Prevention, Fred Hutchinson Cancer Research Center, Seattle, WA 98109-1024, alicia@scharp.org.}

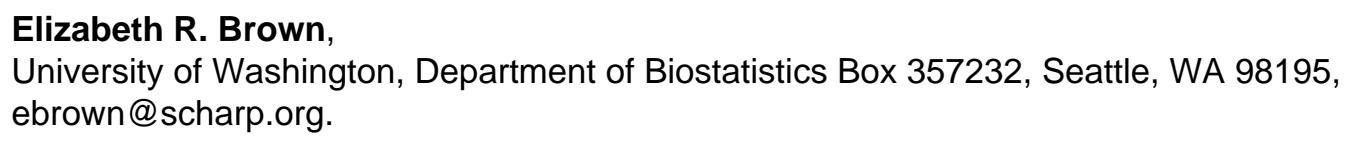

\section{Jennifer S. Read,}

Pediatric, Adolescent and Maternal AIDS Branch, Eunice Kennedy Shriver National Institute of Child Health and Human Development, National Institute of Health, Executive Building, Room 4B11C, 6100 Executive Boulevard, MSC 7510, Bethesda, MD 20892-7510, jennifer_read@nih.gov.

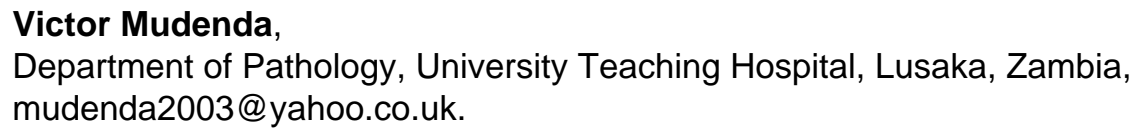

\section{Robert L. Goldenberg,}

Department of Obstetrics and Gynecology, Drexel University College of Medicine, 245 North 15th Street, 17th Floor, Room 17113, Philadelphia, PA 19102, rgoldenb@drexelmed.edu.

\section{Usha Sharma,}

Division of AIDS, National Institute of Allergy and Infectious Diseases, 6700 B Rockledge Drive, Bethesda, MD 20892, usharma@niaid.nih.gov.

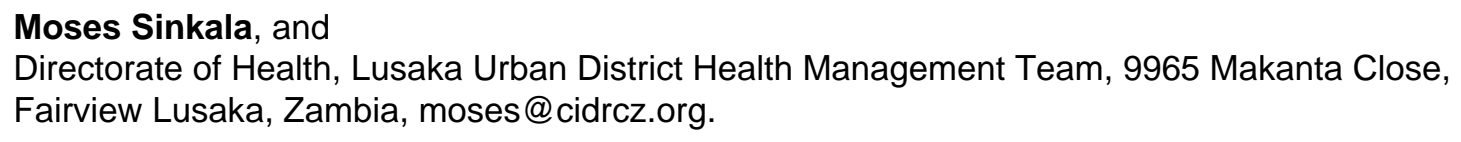

\footnotetext{
Copyright $@ 2009$ by The American Society of Tropical Medicine and Hygiene

*Address correspondence to Department of Community Health, Muhimbili University of Health and Allied Sciences, United Nations Road, PO Box 65001, Dar es Salaam, Tanzania. gmsamanga@muhas.ac.tz.

Disclaimer: The assertions and conclusions presented in this article do not necessarily reflect those of the funding agencies and participating institutions.
} 
Department of Nutrition, Third Floor, Room 329, Harvard School of Public Health, 665 Huntington Avenue, Boston MA 02115, mina@hsph.harvard.edu.

\section{Abstract}

There are few studies of the association between placental malaria (PM) and mother-to-child transmission (MTCT) of human immunodeficiency virus-1 (HIV-1), and the results of published studies are inconsistent. To determine the association between PM and MTCT of HIV-1, we performed a secondary analysis of data from a clinical trial of antibiotics to reduce chorioamnionitis. Data regarding 1,662 HIV-1-infected women with live born singleton and firstborn twin infants with information regarding PM and infant HIV-1 infection status at birth were analyzed. At the time of the study, women did not have access to antiretroviral drugs for treatment of acquired immunodeficiency syndrome but had received nevirapine prophylaxis to reduce the risk of MTCT of HIV-1. Placental malaria was not associated with the infant HIV-1 infection status at birth $(P=0.67)$. Adjustment for maternal plasma viral load and CD4+ cell count did not change these results (odds ratio $=1.06,95 \%$ confidence interval $=0.51-2.20, P=0.87$ ). Placental malaria was more likely to be related to HIV-1 infection at birth among women with low viral load at baseline (P for interaction $=0.08$ ). In conclusion, PM was not associated with infant HIV-1 infection status at birth. The interaction of maternal plasma viral load, PM, and MTCT of HIV-1 warrants further studies.

\section{INTRODUCTION}

Infection with human immunodeficiency virus-1 (HIV-1) and malaria are among the most prevalent infectious diseases worldwide. They disproportionately affect children and adults in sub-Saharan Africa ${ }^{1,2}$ where currently two-thirds of HIV-1 infections, $72 \%$ of acquired immunodeficiency syndrome (AIDS)-related deaths, ${ }^{1}$ and more than one million deaths from malaria occur. ${ }^{2}$ Both HIV-1 and malaria are associated with an increased risk of adverse pregnancy outcomes, such as low birth weight, preterm birth, and stillbirth. ${ }^{3}$ In the absence of prenatal health services and interventions to prevent mother-to-child transmission (MTCT) of HIV-1, an estimated 15-30\% of HIV-1-infected pregnant women transmit the virus to their infants during the in utero and intrapartum periods. ${ }^{4,5}$ An estimated 25 million pregnant women reside in malaria-endemic areas of sub-Saharan Africa and are at risk for malarial infection each year. ${ }^{6-8}$ Maternal malaria increases the risk of severe illness, anemia, and death for the mother, and contributes to spontaneous abortion and stillbirth, and is associated with preterm birth and low birth weight. ${ }^{9-11}$

In addition to their respective disease manifestations, HIV-1 and malaria may interact synergistically in co-infected individuals, and result in an increased risk of adverse health outcomes. $10,12,13$ In studies among pregnant women, the reported frequency and severity of malaria ${ }^{8,10,14-17}$ and risk of adverse pregnancy outcomes $18,19,22$ were increased among HIV-1-infected women compared with HIV-1-uninfected women. Infection with HIV-1 also has been identified as an independent predictor of malaria among pregnant women. ${ }^{8,9,15}$ For example, HIV-1 infection has been associated with an approximately twofold increase in the risk of having placental malaria (PM). ${ }^{8,9}$ Additionally, an estimated one-third to half of malaria infections were attributable to HIV-1 co-infection in a study among HIV-1-infected pregnant women in Kenya. ${ }^{16}$ Co-infection with HIV-1 and malaria during pregnancy also has been associated with increased maternal viral load, ${ }^{3,19-21}$ which along with a lower maternal CD4+ cell count, is a known risk factor for MTCT of HIV-1. ${ }^{21-24}$

Four studies have examined the association between PM and MTCT of HIV-1, and the findings have been inconsistent. A study in Rakai, Uganda, reported that PM was associated 
with a significantly increased risk of MTCT of HIV-1 after controlling for baseline maternal viral load. ${ }^{3}$ However, in studies conducted in Mombasa, Kenya, ${ }^{14}$ Kisumu, Kenya, ${ }^{25}$ and Blantyre, Malawi, ${ }^{21}$ no associations were observed between PM and in utero or peripartum HIV-1 transmission. In contrast, in a study in western Kenya of women who were dually infected with HIV-1 and malaria, higher parasitemia levels ( 210,000 parasites $/ \mu \mathrm{L}$ of blood) were associated with an increased risk of MTCT of HIV-1 (compared with lower parasitemia levels). ${ }^{26}$ In a detailed literature review, ter Kuile and others ${ }^{8}$ concluded that the available evidence was inconsistent with regard to an association between PM and MTCT of HIV-1, and further studies were warranted. We examined the association between PM and MTCT of HIV-1 among women and their infants enrolled in a large clinical trial (HIVNET 024) conducted in Malawi, Zambia and Tanzania.

\section{MATERIALS AND METHODS}

\section{Hivnet 024}

HIVNET 024 was a Phase III, randomized, double-blind, placebo-controlled trial of antibiotics to reduce chorioamnionitis-associated MTCT of HIV-1 and preterm birth. The study protocol was reviewed and approved by the institutional review boards of all study sites in the respective countries and the collaborating U.S. institutions. ${ }^{27}$ The HIVNET 024 trial design and study population have been described in detail elsewhere. ${ }^{27}$ Briefly, this trial was conducted from July 2001 through August 2003 at four sites in three countries in sub-Saharan Africa: Blantyre and Lilongwe, Malawi; Lusaka, Zambia; and Dar es Salaam, Tanzania. After provision of HIV-1 voluntary counseling and testing and determination of HIV-1 infection status, women were enrolled in the trial (at 20-24 weeks gestation) and randomly assigned to receive either antibiotics (erythromycin and metronidazole antenatally and ampicillin and metronidazole intrapartum) or placebo at 20-24 weeks' gestation and at the time of delivery. At three of the four sites, women not infected with HIV-1 also were enrolled and randomized to reduce HIV-1-related stigmatization.

Routine prenatal care was provided to all participants. Fifty-two percent of women received various antimalarial drugs as concomitant medications for clinical symptoms or they received sulfadoxine-pyrimethamine as an intermittent preventive therapy during the second and third trimester of pregnancy. In addition, all women received iron and folate supplements, in accordance with the World Health Organization recommendations and national standard of care guidelines in the respective study sites. Women and their infants received nevirapine for prevention of MTCT of HIV-1 (HIVNET 012 regimen). ${ }^{28}$

After enrollment, women were seen at 28 and 36 weeks gestation and at delivery. Maternal sociodemographic information was recorded at baseline. Additionally, at follow-up visits, physical examination was conducted, and obstetric and clinical histories were obtained. Maternal laboratory examinations included HIV-1 diagnostic testing and CD4+ cell counts at baseline (based on approved site-specific procedures) and measurement of plasma viral load (at the University of North Carolina, Chapel Hill, NC, using the Roche HIV-1 Amplicor Monitor assay, version 1.5 [Roche, Branchburg, NJ]). ${ }^{27}$ Infant HIV-1 diagnostic testing was determined for live born infants at birth and at subsequent study visits using blood samples collected on filter paper cards and examined as previously described ${ }^{27}$ at the University of North Carolina, Chapel Hill. Wherever possible, positive assays were confirmed by analysis of a second blood sample that was collected at a subsequent followup visit.

At delivery, placental, membrane, and umbilical cord samples were collected for histologic examination. Placental samples were sent to the University Teaching Hospital in Lusaka, Zambia, where all final processing and laboratory examinations were performed. To 
diagnose PM, formalin-fixed, paraffin-embedded placental tissue was prepared, cut at $5 \mu$, and stained with hematoxylin and eosin. Diagnosis of PM was based on the presence of trophozoites seen on Hematoxylin and eosin-stained slides but speciation was not performed. In those cases where staining was negative, Giemsa staining was used to rule out the presence of any malaria parasites. Other, more sensitive diagnostic techniques (e.g., histidine-rich protein [HRP-II] immunochemistry and polymerase chain reaction [PCR]) were not available in our setting. The pathologist reading the slides was not aware of the clinical data. The PM parasite density was not determined because our interest was primarily to establish whether the placenta was infected with malaria parasites or not.

\section{Study population and definitions}

The study population for this analysis comprised HIV-1-infected pregnant women enrolled in the HIVNET 024 trial who had known delivery outcomes, a PM evaluation, and gave birth to live born infants with available HIV-1 infection status. Only singletons and firstborn twins were included in the study population. Second-born twins were excluded because HIV-1 infection status of the second twin was likely to be higher because of intrapartum transmission and prolonged contact with maternal blood during delivery. Preterm infants were defined as those born at less than 37 completed weeks gestation. Low birth weight was defined as a birth weight $<2,500$ grams.

\section{Statistical analysis}

Chi-square tests were performed to test for associations between categorical variables and PM. Similarly, $t$ tests were performed to compare the means and Wilcoxon tests to compare the medians of continuous variables by PM status. We compared various background characteristics between women with lower versus higher viral load at baseline. Statistical analyses were performed to examine the association between PM and the infant's HIV-1 infection status at birth. We assumed that any association between PM (an infection that occurs sometimes during pregnancy) and MTCT of HIV-1 would most likely manifest itself at birth (as opposed to later, e.g., at 6-8 weeks or thereafter). To estimate unadjusted and adjusted odds of MTCT of HIV-1, a censored multinomial model was used, as previously described. ${ }^{29}$

We also determined the association between PM with monocytic infiltration in the placental membranes, the decidua of placental floor, the villi, and infiltration at any of these three sites. We further examined the effect of antibiotics compared with placebo on the presence of monocytic infiltration, and on PM. Finally, we assessed whether the association of PM with HIV-1 transmission was modified by the presence of lymphocytic infiltration. Monocytic infiltration in the membranes, decidua of placental floor, or the villi, was categorized as marked, slight, or not seen, and the chi-square or Fisher's exact tests were performed where appropriate to determine whether the associations were significant.

We developed multivariate analyses of the association between PM and HIV-1 transmission, and included factors known to be potential confounders or that had $P$ values $<0.2$ in univariate analyses. Multivariate models were adjusted for infant factors (preterm birth and low birth weight) and maternal factors (trichomoniasis, bacterial vaginosis, CD4+ cell counts, plasma viral load, and randomization arm). Plasma viral load values were dichotomized into lower $(<55,000$ copies $/ \mathrm{mL})$ and higher $(\geq 55,000$ copies $/ \mathrm{mL})$ values. Plasma viral load values of $\geq 55,000$ copies $/ \mathrm{mL}$ ) have been used to define advanced HIV-1 disease and as an indication for initiation of antiretroviral therapy. ${ }^{30}$ Wald chi-square tests were performed to test for significance of covariates. A sensitivity analysis was conducted to assess the potential impact of missing data on the results. We conducted the analyses described under two imputation methods: 1) multiple imputation, ${ }^{31}$ and 2) a worst case 
scenario where a) all mothers who gave birth to HIV-1-infected infants and had missing PM evaluations were imputed to be positive for malaria, and b) mothers with missing PM evaluations and infants not infected with HIV-1 were assumed to be negative for malaria. All statistical analyses were conducted using SAS version 9.1 (SAS Institute, Cary, NC).

\section{RESULTS}

\section{Size and characteristics of the study population}

Of 2,661 women randomized, 2,466 (92.7\%) were followed until delivery. Of these, 2,126 women $(86.2 \%)$ were infected with HIV-1 and had live-born infants (singletons or first-born twins). Of these 2,126 women, PM evaluations were available for 1,750 women $(82.3 \%)$ and not available for 376 women (17.7\%) ( Figure 1). The characteristics of these 2,126 women according to whether a PM evaluation was available are shown in Table 1 . Those women without a PM evaluation were slightly younger and were more likely to deliver a preterm, lowbirth weight, or stillborn infant. The characteristics of the 1,750 women with PM evaluations (and their infants), according to presence or absence of PM, are shown in Table 2 . Those women with PM were younger and had higher plasma viral load values. Their infants had slightly lower gestational ages and birth weights. Of the 1,750 women with PM evaluations, 1,662 (95\%) had infants with HIV-1 diagnostic test results available from the birth visit. Therefore, the study population comprised 1,662 mother-child pairs.

Characteristics of the study population according to maternal plasma viral load valu es are shown in Table 3 . Compared with women with lower viral loads, those women with higher plasma viral load values had less education, were more likely to be multiparous, had lower hemoglobin values, had lower body mass indices, and lower CD4+ counts. Their infants were more likely to be born preterm, have lower birth weights, and be female.

\section{Malaria and MTCT of HIV-1}

In univariate analyses, there were no significant differences in MTCT of HIV-1 according to the presence or absence of PM ( $P=0.67)$. Of 1,662 mother-infant pairs, 6.3\% (104 of 1,662) mothers had PM. Of the 104 infants whose mothers had PM, 8.7\% (95\% confidence interval $[\mathrm{CI}]=3.3-14.1$ ) were infected with HIV-1 at birth compared with $7.5 \%$ of infants of 1,558 mothers without PM (95\% CI $=6.2-8.8)$. In multivariate analyses, $\mathrm{PM}$ was not associated with HIV-1 infection status in the newborn (odds ratio $[\mathrm{OR}]=1.06,95 \% \mathrm{CI}=$ $0.51-2.20, P=0.87$ ) ( Table 4 ). In sensitivity analyses under the worst case scenario, the odds of HIV-1 infection at birth for the presence of PM were 1.52 times the odds for the absence of PM $(\mathrm{OR}=1.52,95 \% \mathrm{CI}=1.00-2.31, P=0.05)$. Multiple imputation did not provide evidence of a relationship between PM and HIV-1 infection at birth $(\mathrm{OR}=1.19$, $95 \% \mathrm{CI}=0.38-3.71, P=0.77)$.

As expected, women with lower CD4+ counts and higher plasma viral loads were more likely to transmit HIV-1 to their infants: a maternal plasma viral load $\geq 55,000$ copies $/ \mathrm{mL}$ was significantly associated with a 2.3 -fold increase $(\mathrm{OR}=2.31,95 \% \mathrm{CI}=1.55-3.44, P<$ 0.001 ) in the odds of HIV-1 infection in the newborn compared with a maternal viral load < 55,000 copies $/ \mathrm{mL} .{ }^{28}$ Similarly, a maternal CD4+ cell count $<200$ cells $/ \mu \mathrm{L}$ was associated with a $64 \%$ increase in the odds of HIV-1 infection in the newborn $(\mathrm{OR}=1.64,95 \% \mathrm{CI}=$ $1.03-2.60, P=0.04$ ) compared with a maternal CD4+ cell count 2350 cells $/ \mu \mathrm{L}$, and CD4+ cell counts of 200-350 cells/ $\mu \mathrm{L}$ were not significantly associated with the HIV-1 infection status of the newborn $(\mathrm{OR}=0.96,95 \% \mathrm{CI}=0.59-1.57, P=0.88)$.

We examined the hypothesis that PM may be associated with higher monocytic infiltration of the placenta, resulting in a higher risk of HIV-1 transmission. Women with PM had higher monocytic infiltration in the decidua of the placental floor and membranes (55\%) 
compared with women without PM (43\%) ( $P=0.02$ ). However, there was no association between PM and monocytic infiltration of the membranes alone ( $P=0.77)$, of the placental villi ( $P=1.0$ ), or of any of the three sites ( $P=0.20$ ). Compared with placebo, antibiotics provided experimentally as part of the trial had no effect on the risk of monocytic infiltration or PM, and the relationship between PM and HIV-1 transmission was not modified by the presence of monocytic infiltration at any of the sites of the placenta.

\section{Potential interactions between maternal viral load and PM}

The potential interactions between maternal viral load and PM infection and their relationship to HIV-1 infection at birth also were explored. Results from these analyses are summarized in Table 5 . Placental malaria was more likely to be related to HIV-1 infection at birth among women with lower viral load at baseline ( $\mathrm{P}$ for interaction $=0.08)$. Among women with viral loads $<55,000$ copies $/ \mathrm{mL}$, the odds of HIV-1 infection at birth were 2.00 times greater for women with $\mathrm{PM}$ compared with women without placental malaria $(\mathrm{OR}=$ $2.00,95 \% \mathrm{CI}=0.81-4.90, P=0.14$ ) Among women with viral loads $\geq 55,000$ copies $/ \mathrm{mL}$, the presence of PM was not associated with the risk of MTCT of HIV-1 $(P=0.28)$.

\section{DISCUSSION}

In this prospective study of HIV-1-infected women, PM was not associated with MTCT of HIV-1. Except for a recent study from Uganda, ${ }^{22}$ the overall results of the current study are consistent with studies in Malawi, ${ }^{21}$ the Kenyan coast ${ }^{25}$ and Kisumu. ${ }^{26}$ Inconsistencies in the results of previous studies of PM and MTCT of HIV-1 are likely caused by, at least in part, to the epidemiology of malaria in different settings, which could affect maternal immunity. Furthermore, these inconsistencies could be also be caused by differences in the techniques that were used to diagnose PM (e.g., staining with hematoxylin and eosin, HRPII immunohistochemical staining, or PCR). Histologic examination is less sensitive compared with HRP-II immunochemistry staining 22 and PCR, but these more sensitive techniques were not available in our setting; use of low-sensitivity malaria diagnoses may reduce the power to detect an association between PM and MTCT.

Maternal plasma viral load and CD4+ cell counts were associated with MTCT of HIV-1, as has been demonstrated in previous studies. ${ }^{22-25,32-35}$ Of greater interest, PM was associated with higher risk of MTCT among women with low viral load and not among those with high viral load. Women with lower viral load were more likely to be primgravidae, among whom malaria tends to be more severe. Conversely, women with higher viral loads may have had HIV-1 infection for a longer period, and being multigravid women, they may have experienced malaria in previous pregnancies, resulting in partial pregnancy-specific immunity to malaria.

The major strengths of the current analysis are the study design and the large sample size. However, certain limitations should be considered. For example, only $80 \%$ of placental samples were assessed for PM because of logistic constraints in collection, processing, and examination of specimens at study sites. Placental samples were also missing from some women who delivered away from the four study sites. Lack of availability of PM data was associated with increased risk of preterm birth and infant low birth weight, factors that are associated with MTCT of HIV-1. Women for whom PM data were not available were more likely to have HIV-1-infected infants. These factors suggest that our findings may be biased towards the null. Assessment of PM parasite density was not performed because we examined the placentas primarily to determine whether the placentas were infected with malaria or not. Density of PM parasites may be an important predictor of MTCT of HIV-1. ${ }^{26}$ Moreover, some women with low density malaria infections may have been misclassified as negative for PM infections. As a result, potential non-differential 
misclassification of the exposure would be expected to bias findings towards the null hypothesis. Assessment of malaria parasite density in future studies using more sensitive and specific techniques may further the understanding of the relationship between PM and MTCT of HIV-1.

Several mechanisms have been identified by which PM may affect MTCT of HIV-1. For example, malarial infection may up-regulate HIV-1 CCR5 chemokine co-receptor expression on placental macrophages, ${ }^{35}$ and increase placental viral loads, ${ }^{20}$ thereby increasing the risk of HIV-1 transmission. Additionally, PM infection and subsequent inflammatory responses may damage the integrity of the placenta and increase MTCT of HIV-1. ${ }^{3}$ Although we noted that PM was associated with monocytic infiltration in the decidua of placental floor, no associations were noted with infiltration at other placental sites, and in general infiltration did not modify the relation between PM and MTCT. Unfortunately CC chemokines and cytokine measures were not available in this study, data that could be obtained in future studies to shed more light on the inter-relationships of malaria and HIV-1 infection. Malaria may also affect MTCT of HIV-1 indirectly, through its adverse effects on maternal and infant immune function and pregnancy outcomes (e.g., low birth weight). ${ }^{18,19,22,36-38}$ For example, in a study in Zimbabwe, maternal malaria and HIV-1 co-infection were independently associated with increased risks of low birth weight, low Apgar scores, fetal growth restriction, and maternal, perinatal, and early infant deaths. 18

The relationship between PM and MTCT of HIV-1 warrants further investigation, including whether and how a maternal plasma viral load may modify this association. When we conducted this study at the four sites in sub-Saharan Africa, study women who reached advanced stages of HIV-1 did not have access to antiretroviral drugs for treatment of AIDS as it is currently the case according to the national and international guidelines. However, most women and their newborns were given nevirapine prophylaxis for prevention of MTCT of HIV-1. Currently, several countries in sub-Saharan are scaling-up interventions to prevent MTCT of HIV-1 and to improve care and treatment of HIV-1-infected women. Whether PM affects the risk of MTCT of HIV-1 among HIV-1- infected women receiving appropriate antiretroviral prophylaxis or treatment remains to be assessed.

\section{Acknowledgments}

\footnotetext{
We thank Julia Finkelstein and Saurabh Mehta (Harvard School of Public Health, Boston, Massachusetts), Anthony Mwatha (SCHARP, Seattle, Washington), and Steve Meshnick and Susan Fiscus (School of Public Health, University of North Carolina) for critical reviews of earlier versions of this article.

Financial support: This study was supported by the HIV Network for Prevention Trials (HIVNET) and sponsored by the National Institute of Allergy and Infectious Diseases (NIAID), National Institutes of Health, and the Department of Health and Human Services through contract \#N01-AI-35173 with Family Health International; contract \#N01-AI-45200 with Fred Hutchinson Cancer Research Center; and subcontract \#N01-AI-35173-117/412 with Johns Hopkins University. This work was also sponsored by the NIAID, the Eunice Kennedy Shriver National Institute of Child Health and Human Development, the National Institute on Drug Abuse, the National Institute of Mental Health, and the Office of AIDS Research at the National Institutes of Health, the U.S. Department of Health and Human Services, Harvard University (U01-AI-48006), Johns Hopkins University (U01-AI-48005), and the University of Alabama at Birmingham (U01-AI-47972). Nevirapine (Viramune; Boehringer Ingelheim GmbH, Ingelheim, Germany) was provided by Boehringer Ingelheim Pharmaceuticals, Incorporated.
}

\section{APPENDIX: HIVNET 024 PROTOCOL TEAM PROTOCOL CO-CHAIRS}

Taha E. Taha (Johns Hopkins University Bloomberg School of Public Health); Robert Goldenberg (University of Alabama at Birmingham); In-Country Co-Chairs/Investigators of Record: Newton Kumwenda, George Kafulafula (Blantyre, Malawi); Francis Martinson (Lilongwe, Malawi); Gernard Msamanga (Dar es Salaam, Tanzania); Moses Sinkala, Jeffrey 
Stringer (Lusaka, Zambia); US Co-Chairs: Irving Hoffman (University of North Carolina, Chapel Hill); Wafaie Fawzi (Harvard School of Public Health); In-Country Investigators, Consultants, and Key Site Personnel: Robin Broadhead, George Liomba, Johnstone Kumwenda, Tsedal Mebrahtu, Pauline Katunda, Maysoon Dahab (Blantyre, Malawi); Peter Kazembe, David Chilongozi, Charles Chasela, George Joaki, Willard Dzinyemba, Sam Kamanga (Lilongwe, Malawi); Eligius Lyamuya, Charles Kilewo, Karim Manji, Sylvia Kaaya, Said Aboud, Muhsin Sheriff, Elmar Saathoff, Priya Satow, Illuminata Ballonzi, Gretchen Antelman, Edgar Basheka (Dar es Salaam, Tanzania); Victor Mudenda, Christine Kaseba, Maureen Njobvu, Makungu Kabaso, Muzala Kapina, Anthony Yeta, Seraphine Kaminsa, Constantine Malama, Dara Potter, Maclean Ukwimi, Alison Taylor, Patrick Chipaila, Bernice Mwale (Lusaka, Zambia); US Investigators, Consultants, and Key Site Personnel: Priya Joshi, Ada Cachafeiro, Shermalyn Greene, Marker Turner, Melissa Kerkau, Paul Alabanza, Amy James, Som Siharath, Tiffany Tribull (University of North Carolina, Chapel Hill); Saidi Kapiga, George Seage (Harvard School of Public Health); Sten Vermund, William Andrews, Deedee Lyon (University of Alabama at Birmingham); National Institute of Allergy and Infectious Diseases Medical Officer: Samuel AdeniyiJones; National Institute of Child Health and Human Development Medical Officer: Jennifer S. Read; Protocol Pharmacologist: Scharla Estep; Protocol Statisticians: Elizabeth R. Brown, Thomas R. Fleming, Anthony Mwatha, Lei Wang, Ying Q. Chen; Protocol Virologist: Susan Fiscus; Protocol Operations Coordinator: Lynda Emel; Data Coordinators: Debra J. Lands, Ceceilia J. Dominique; Systems Analyst Programmers: Alice H. Fisher, Martha Doyle; Protocol Specialist: Megan Valentine.

\section{REFERENCES}

1. UNAIDS. AIDS Epidemic Update: 2007. UNAIDS; Geneva: 2007.

2. Abu-Raddad LJ, Patnaik P, Kublin JG. Dual Infection with HIV-1 and malaria fuels the spread of both diseases in sub-Saharan Africa. Science. 2006; 314:1603-1606. [PubMed: 17158329]

3. Brahmbhatt H, Kigozi G, Wabwire-Mangen F, Serwadda D, Sewankambo N, Lutalo T, Wawer MJ, Abramowsky C, Sullivan D, Gray R. The effects of placental malaria on mother-to-child HIV transmission in Rakai, Uganda. AIDS. 2003; 17:2539-2541. [PubMed: 14600529]

4. Kourtis AP, Lee FK, Abrams EJ, Jamieson DJ, Bulterys M. Mother-to-child transmission of HIV-1: timing and implications for prevention. Lancet Infect Dis. 2006; 6:726-732. [PubMed: 17067921]

5. De Cock KM, Fowler MG, Mercier E, de Vincenzi I, Saba J, Hoff E, Alnwick DJ, Rogers M, Shaffer N. Prevention of mother-to-child HIV transmission in resource-poor countries: translating research into policy and practice. JAMA. 2000; 283:1175-1182. [PubMed: 10703780]

6. Guyatt HL, Snow RW. The epidemiology and burden of Plasmodium falciparum-related anemia among pregnant women in sub-Saharan Africa. Am J Trop Med Hyg. 2001; 64:36-44. [PubMed: 11425176]

7. Steketee RW, Nahlen BL, Parise ME, Menendez C. The burden of malaria in pregnancy in malariaendemic areas. Am J Trop Med Hyg. 2001; 64:28-35. [PubMed: 11425175]

8. ter Kuile FO, Parise ME, Verhoeff FH, Udhayakumar V, Newman RD, van Eijk AM, Rogerson SJ, Steketee RW. The burden of co-infection with human immunodeficiency virus type 1 and malaria in pregnant women in sub-Saharan Africa. Am J Trop Med Hyg. 2004; 71:41-54. [PubMed: 15331818]

9. Parise ME, Ayisi JG, Nahlen BL, Schultz LJ, Roberts JM, Misore A, Muga R, Oloo AJ, Steketee RW. Efficacy of sulfadoxine-pyrimethamine for prevention of placental malaria in an area of Kenya with a high prevalence of malaria and human immunodeficiency virus infection. Am J Trop Med Hyg. 1998; 59:813-822. [PubMed: 9840604]

10. Steketee RW, Wirima JJ, Bloland PB, Chilima B, Mermin JH, Chitsulo L, Breman JG. Impairment of a pregnant woman's acquired ability to limit Plasmodium falciparum by infection with human immunodeficiency virus type-1. Am J Trop Med Hyg. 1996; 55:42-49. [PubMed: 8702036] 
11. Villamor E, Msamanga G, Aboud S, Urassa W, Hunter DJ, Fawzi WW. Adverse perinatal outcomes of HIV-1 infected women in relation to malaria parasitemia in maternal and umbilical cord blood. Am J Trop Med Hyg. 2005; 73:694-697. [PubMed: 16222011]

12. French N, Gilks CF. Royal Society of Tropical Medicine and Hygiene meeting at Manson House, London, 18 March 1999. Fresh from the field: some controversies in tropical medicine and hygiene. HIV and malaria, do they interact? Trans R Soc Trop Med Hyg. 2000; 94:233-237. [PubMed: 10974985]

13. Abu-Raddad LJ, Patnaik P, Kublin JG. Dual infection with HIV and malaria fuels the spread of both diseases in sub-Saharan Africa. Science. 2006; 314:1603-1606. [PubMed: 17158329]

14. Inion I, Mwanyumba F, Gaillard P, Chohan V, Verhofstede C, Claeys P, Mandaliya K, Van Marck E, Temmerman M. Placental malaria and perinatal transmission of human immunodeficiency virus type 1. J Infect Dis. 2003; 188:1675-1678. [PubMed: 14639538]

15. Ladner J, Leroy V, Simonon A, Karita E, Bogaerts J, De Clercq A, Van De Perre P, Dabis F. HIV infection, malaria, and pregnancy: a prospective cohort study in Kigali, Rwanda. Am J Trop Med Hyg. 2002; 66:56-60. [PubMed: 12135269]

16. van Eijk AM, Ayisi JG, ter Kuile FO, Misore AO, Otieno JA, Rosen DH, Kager PA, Steketee RW, Nahlen BL. HIV increases the risk of malaria in women of all gravidities in Kisumu, Kenya. AIDS. 2003; 17:595-603. [PubMed: 12598780]

17. Verhoeff FH, Brabin BJ, Hart CA, Chimsuku L, Kazembe P, Broadhead RL. Increased prevalence of malaria in HIV-infected pregnant women and its implications for malaria control. Trop Med Int Health. 1999; 4:5-12. [PubMed: 10203167]

18. Ticconi C, Mapfumo M, Dorrucci M, Naha N, Tarira E, Pietropolli A, Rezza G. Effect of maternal $\mathrm{HIV}$ and malaria infection on pregnancy and perinatal outcome in Zimbabwe. J Acquir Immune Defic Syndr. 2003; 34:289-294. [PubMed: 14600573]

19. Ayisi JG, van Eijk AM, ter Kuile FO, Kolczak MS, Otieno JA, Misore AO, Kaga PA, Steketee RW, Nahlen BL. The effect of dual infection with HIV and malaria on pregnancy outcome in western Kenya. AIDS. 2003; 17:585-594. [PubMed: 12598779]

20. Kublin JG, Patnaik P, Jere CS, Miller WC, Hoffman IF, Chimbiya N, Pendame R, Taylor TE, Molyneux ME. Effect of Plasmodium falciparum malaria on concentration of HIV-1 RNA in the blood of adults in rural Malawi: a prospective cohort study. Lancet. 2005; 365:233-240. [PubMed: 15652606]

21. Mwapasa V, Rogerson SJ, Molyneux ME, Abrams ET, Kamwendo DD, Lema VM, Tadesse E, Chaluluka E, Wilson PE, Meshnick SR. The effect of Plasmodium falciparum malaria on peripheral and placental HIV-1 RNA concentrations in pregnant Malawian women. AIDS. 2004; 18:1051-1059. [PubMed: 15096809]

22. Brahmbhatt H, Sullivan D, Kigozi G, Askin F, Wabwire-Mangen F, Serwadda D, Sewankambo N, Lutalo T, Wawer M, Gray R. Association of HIV and malaria with mother-to-child transmission birth outcomes and child mortality. AIDS. 2008; 47:472-476.

23. Fawzi W, Msamanga G, Renjifo B, Spiegelman D, Urassa E, Hashemi L, Antelman G, Essex M, Hunter D. Predictors of intrauterine and intrapartum transmission of HIV-1 among Tanzanian women. AIDS. 2001; 15:1157-1165. [PubMed: 11416718]

24. Mofenson LM, Lambert JS, Stiehm ER, Bethel J, Meyer WA III, Whitehouse J, Moye J Jr, Reichelderfer P, Harris DR, Fowler MG, Mathieson BJ, Nemo GJ. Risk factors for perinatal transmission of human immunodeficiency virus type 1 in women treated with zidovudine. Pediatric AIDS Clinical Trials Group Study 185 Team. N Engl J Med. 1999; 341:385-393. [PubMed: 10432323]

25. John GC, Nduati RW, Mbori-Ngacha DA, Richardson BA, Panteleeff D, Mwatha A, Overbaugh J, Bwayo J, Ndinya-Achola JO, Kreiss JK. Correlates of mother-to-child human immunodeficiency virus type 1 (HIV-1) transmission: association with maternal plasma HIV-1 RNA load, genital HIV-1 DNA shedding, and breast infections. J Infect Dis. 2001; 183:206-212. [PubMed: 11120927]

26. Ayisi JG, van Eijk AM, Newman RD, ter Kuile FO, Shi YP, Yang C, Kolczak MS, Otieno JA, Misore AO, Kager PA, Lal RB, Steketee RW, Nahlen BL. Maternal malaria and perinatal HIV transmission, western Kenya. Emerg Infect Dis. 2004; 10:643-652. [PubMed: 15200854] 
27. Taha TE, Brown ER, Hoffman IF, Fawzi W, Read JS, Sinkala M, Martinson FE, Kafulafula G, Msamanga G, Emel L, Adeniyi-Jones S, Goldenberg R. A phase III clinical trial of antibiotics to reduce chorioamnionitis-related perinatal HIV-1 transmission. AIDS. 2006; 20:1313-1321. [PubMed: 16816561]

28. Guay LA, Musoke P, Fleming T, Bagenda D, Allen M, Nakabiito C, Sherman J, Bakaki P, Ducar C, Deseyve M, Emel L, Mirochnick M, Fowler MG, Mofenson L, Miotti P, Dransfield K, Bray D, Mmiro F, Jackson JB. Intrapartum and neonatal single-dose nevirapine compared with zidovudine for prevention of mother-to-child transmission of HIV-1 in Kampala, Uganda: HIVNET 012 randomised trial. Lancet. 1999; 354:795-802. [PubMed: 10485720]

29. Gard, CC.; Brown, ER. A censored multinomial regression model for perinatal mother-to-child transmission of HIV. University of Washington Biostatistics; Seattle, WA: 2007. Working Paper Series. Working Paper 314

30. Guidelines for the Use of Antiretroviral Agents in HIV-1 Infected Adults and Adolescents. Department of Health and Human Services; Jan 29. 2008 Available at: http://aidsinfo.nih.gov/ contentfiles/AdultandAdolescentGL.pdf [Accessed July 10, 2008]

31. Rubin DB. Multiple imputation after 18+ years (with discussion). J Am Stat Assoc. 1996; 91:473489.

32. Gallagher M, Malhotra I, Mungai PL, Wamachi AN, Kioko JM, Ouma JH, Muchiri E, King CL. The effects of maternal helminth and malaria infections on mother-to-child HIV transmission. AIDS. 2005; 19:1849-1855. [PubMed: 16227793]

33. Mwanyumba F, Gaillard P, Inion I, Verhofstede C, Claeys P, Chohan V, Vansteelandt S, Mandaliya K, Praet M, Temmerman M. Placental inflammation and perinatal transmission of HIV-1. J Acquir Immune Defic Syndr. 2002; 29:262-269. [PubMed: 11873075]

34. Taha TE, Nour S, Kumwenda NI, Broadhead RL, Fiscus SA, Kafulafula G, Nkhoma C, Chen S, Hoover DR. Gender differences in perinatal HIV acquisition among African infants. Pediatrics. 2005; 115:e167-e172. [PubMed: 15687425]

35. European Collaborative Study. Risk factors for mother-to-child transmission of HIV-1. Lancet. 1992; 339:1007-1012. [PubMed: 1349050]

36. Tkachuk AN, Moormann AM, Poore JA, Rochford RA, Chensue SW, Mwapasa V, Meshnick SR. Malaria enhances expression of CC chemokine receptor 5 on placental macrophages. J Infect Dis. 2001; 183:967-972. [PubMed: 11237815]

37. Xiao L, Owen SM, Rudolph DL, Lal RB, Lal AA. Plasmodium falciparum antigen-induced human immunodeficiency virus type 1 replication is mediated through induction of tumor necrosis factoralpha. J Infect Dis. 1998; 177:437-445. [PubMed: 9466533]

38. Bloland PB, Wirima JJ, Steketee RW, Chilima B, Hightower A, Breman JG. Maternal HIV infection and infant mortality in Malawi: evidence for increased mortality due to placental malaria infection. AIDS. 1995; 9:721-726. [PubMed: 7546417] 


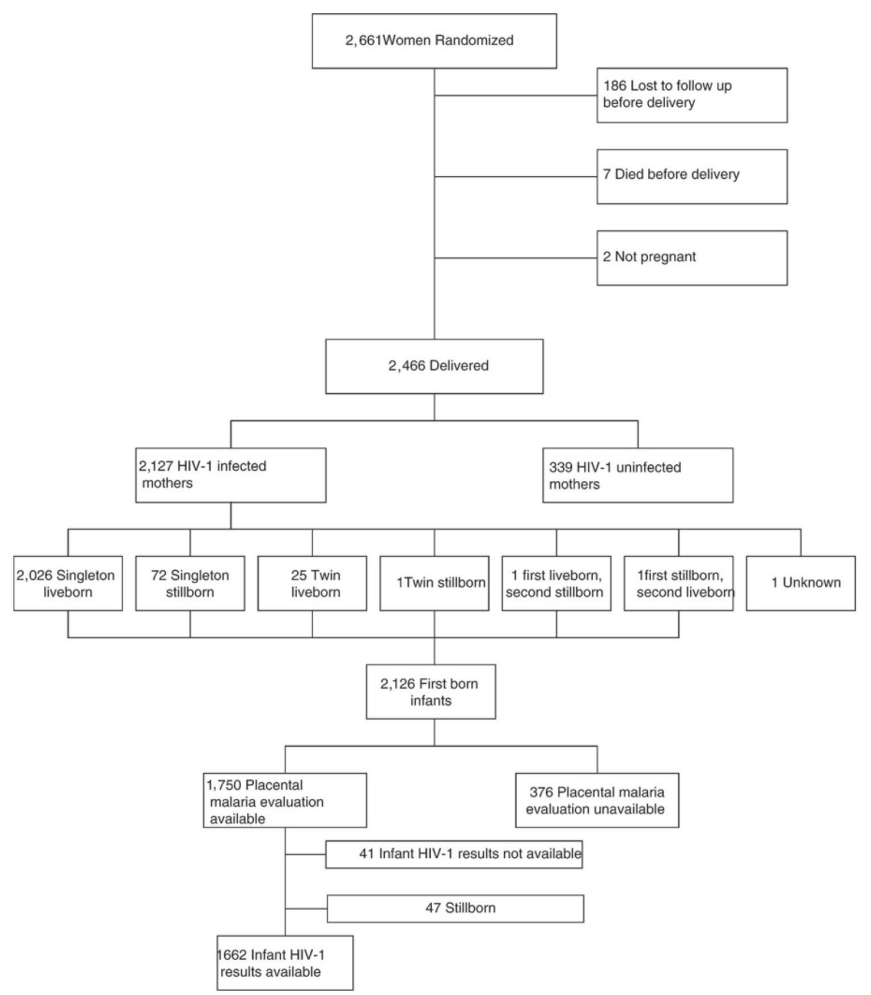

Figure 1.

Study profile. 
Table 1

Characteristics of 2,126 mother-child pairs, by availability of placental malaria evaluation

\begin{tabular}{|c|c|c|c|c|}
\hline Characteristic & Category & $\begin{array}{l}\text { Placental malaria evaluation available } \\
\qquad(\mathrm{n}=1,750)\end{array}$ & $\begin{array}{l}\text { Malaria evaluation not available }(n= \\
\text { 376) }\end{array}$ & $P$ \\
\hline Age, years & Mean $\pm \mathrm{SE}$ & $25.4 \pm 0.1$ & $24.8 \pm 0.3$ & 0.02 \\
\hline Gestational age, weeks & Mean \pm SE & $38.8 \pm 0.1$ & $37.6 \pm 0.3$ & $<0.001$ \\
\hline Hemoglobin, g/dL & Mean \pm SE & $10.1 \pm 0.03$ & $10.2 \pm 0.1$ & 0.15 \\
\hline \multirow[t]{4}{*}{$\mathrm{CD} 4+$ cell count, cells $/ \mu \mathrm{L}$} & Mean \pm SE & $373 \pm 6$ & $375 \pm 11$ & 0.92 \\
\hline & $<200$ & $362 / 1,570(23.1 \%)$ & $68 / 345(19.7 \%)$ & 0.40 \\
\hline & $200-349$ & $456 / 1,570(29.0 \%)$ & $104 / 345(30.1 \%)$ & \\
\hline & $\geq 350$ & $752 / 1,570(47.9 \%)$ & $173 / 345(50.1 \%)$ & \\
\hline \multirow[t]{3}{*}{ Plasma viral load, copies $/ \mathrm{mL}$} & Mean \pm SE & $4.3 \pm 0.02$ & $4.3 \pm 0.04$ & 0.18 \\
\hline & $<55,000$ & $1,163 / 1,663(69.9 \%)$ & $236 / 357(66.1 \%)$ & 0.15 \\
\hline & $\geq 55,000$ & $500 / 1,663(30.1 \%)$ & $121 / 357(33.9 \%)$ & \\
\hline \multirow[t]{2}{*}{ Preterm birth } & No & $1,334 / 1,750(76.2 \%)$ & $245 / 376(65.2 \%)$ & $<0.001$ \\
\hline & Yes & $416 / 1,750(23.8 \%)$ & $131 / 376(34.8 \%)$ & \\
\hline Birth weight, grams & Mean \pm SE & $2,950 \pm 14$ & $2,848 \pm 37$ & 0.006 \\
\hline \multirow[t]{2}{*}{ Low birth weight } & Yes & $235 / 1,700(13.8 \%)$ & $53 / 269(19.7 \%)$ & 0.01 \\
\hline & No & $1,465 / 1,700(86.2 \%)$ & $216 / 269(80.3 \%)$ & \\
\hline \multirow[t]{2}{*}{ Stillborn } & Yes & $47 / 1,750(2.7 \%)$ & $27 / 376(7.2 \%)$ & $<0.001$ \\
\hline & No & $1,703 / 1,750(97.3 \%)$ & $349 / 376(92.8 \%)$ & \\
\hline
\end{tabular}


Table 2

Characteristics of 1,750 mother-child pairs, according to presence or absence of placental malaria*

\begin{tabular}{|c|c|c|c|c|c|}
\hline & & All $(n=1,750)$ & $\begin{array}{c}\text { Placental malaria } \\
\text { negative }(n=1,643)\end{array}$ & $\begin{array}{l}\text { Placental malaria } \\
\text { positive }(n=107) \\
\end{array}$ & \\
\hline Characteristic & Category & $\%$ or Statistic & $\%$ or Statistic & $\%$ or Statistic & $P$ \\
\hline Age, years & Mean \pm SE & $25.4 \pm 0.1$ & $25.5 \pm 0.1$ & $24.3 \pm 0.4$ & 0.01 \\
\hline Education, years & Median (Q1-Q3) & $7.0(5-9)$ & $7.0(5-9)$ & $7.0(3-8)$ & 0.08 \\
\hline Parity & Median (Q1-Q3) & $3.0(2-4)$ & $3.0(2-4)$ & $3.0(2-4)$ & 0.92 \\
\hline \multirow[t]{4}{*}{ CD $4+$ cell counts, cells $/ \mu \mathrm{L}$} & Mean \pm SE & $373 \pm 6$ & $374 \pm 6$ & $361 \pm 20$ & 0.56 \\
\hline & $<200$ & $362 / 1,750(23.1 \%)$ & $342 / 1,473(23.2 \%)$ & $20 / 97(20.6 \%)$ & 0.53 \\
\hline & $200-349$ & $456 / 1,750(29.0 \%)$ & $423 / 1,473(28.7 \%)$ & $33 / 97(34.0 \%)$ & \\
\hline & $\geq 350$ & $752 / 1,750(47.9 \%)$ & $708 / 1,473(48.1 \%)$ & $44 / 97(45.4 \%)$ & \\
\hline Plasma viral load (log) & Mean $\pm \mathrm{SE}$ & $4.3 \pm 0.02$ & $4.3 \pm 0.02$ & $4.5 \pm 0.07$ & 0.001 \\
\hline \multirow[t]{2}{*}{ Plasma viral load, copies/mL } & $<55,000$ & $1,163 / 1,663(69.9 \%)$ & $1,101 / 1,558(70.7 \%)$ & $62 / 105(59.1 \%)$ & 0.01 \\
\hline & $\geq 55,000$ & $500 / 1,663(30.1 \%)$ & $457 / 1,558(29.3 \%)$ & $43 / 105(40.9 \%)$ & \\
\hline Hemoglobin, g/dL & Mean $\pm \mathrm{SE}$ & $10.1 \pm 0.03$ & $10.1 \pm 0.03$ & $9.8 \pm 0.2$ & 0.05 \\
\hline Gestational age, weeks & Mean $\pm \mathrm{SE}$ & $38.8 \pm 0.1$ & $38.8 \pm 0.1$ & $38.1 \pm 0.3$ & 0.04 \\
\hline Birth weight, ${ }^{\dagger}$ grams & Mean \pm SE & $2,950 \pm 14$ & $2,961 \pm 14$ & $2,786 \pm 54$ & 0.002 \\
\hline \multirow[t]{2}{*}{ Low birth weight ${ }^{\dagger}$} & Yes & $235 / 1,700(13.8 \%)$ & $216 / 1,594(13.6 \%)$ & $19 / 106(17.9 \%)$ & 0.21 \\
\hline & No & $1,465 / 1,700(86.2 \%)$ & $1,378 / 1,594(86.4 \%)$ & $87 / 106(82.1 \%)$ & \\
\hline \multirow[t]{2}{*}{ Stillborn } & Yes & $47 / 1,750(2.7 \%)$ & $46 / 1,643(2.8 \%)$ & $1 / 107(0.9 \%)$ & 0.25 \\
\hline & No & $1,703 / 1,750(97.3 \%)$ & $1,597 / 1,643(97.2 \%)$ & $106 / 107(99.1 \%)$ & \\
\hline \multirow[t]{2}{*}{ Infant HIV-1 results } & Yes & $1,662 / 1,703(97.6 \%)$ & $1,558 / 1,597(97.6 \%)$ & $104 / 106(98.1 \%)$ & 0.72 \\
\hline & No & $41 / 1,703(2.4 \%)$ & $39 / 1,597(2.4 \%)$ & $2 / 106(1.9 \%)$ & \\
\hline
\end{tabular}

* $\mathrm{Q} 1$ = first quartile; Q3 = third quartile; HIV-1 = human immunodeficiency virus-1.

${ }^{\dagger}$ Not available for stillborn infants. 
Table 3

Characteristics of 1,662 mother-child pairs, according to maternal plasma viral load*

\begin{tabular}{|c|c|c|c|c|c|c|}
\hline \multirow[b]{2}{*}{ Characteristic } & \multirow[b]{2}{*}{ Category } & \multirow{2}{*}{$\begin{array}{l}\text { All }(\mathrm{n}=1, \mathbf{6 6 2}) \\
\% \text { or Statistic }\end{array}$} & \multirow{2}{*}{$\begin{array}{c}\begin{array}{c}\text { Missing viral } \\
\text { load } \\
(\mathbf{n}=\mathbf{8 2})\end{array} \\
\text { \% or Statistic }\end{array}$} & \multirow{2}{*}{ 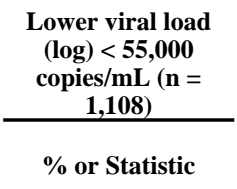 } & \multirow{2}{*}{$\begin{array}{c}\begin{array}{c}\text { Higher viral load } \\
(\log ) \geq 55,000 \\
\text { copies/mL }(\mathrm{n}= \\
472)\end{array} \\
\begin{array}{c}\text { \% or Statistic } \\
\text { क }\end{array}\end{array}$} & \multirow[b]{2}{*}{$P^{\dagger}$} \\
\hline & & & & & & \\
\hline Maternal age, years & Mean \pm SE & $25.4 \pm 0.12$ & $25.0 \pm 0.58$ & $25.3 \pm 0.1$ & $25.5 \pm 0.2$ & 0.39 \\
\hline $\begin{array}{l}\text { Maternal education, } \\
\text { years }\end{array}$ & Median (Q1-Q3) & $7.0(5-9)$ & $8.0(6-9)$ & $7.0(5-9)$ & $7.0(4-9)$ & 0.03 \\
\hline \multirow[t]{4}{*}{ Parity } & Median (Q1-Q3) & $3.0(2-4)$ & $2.5(2-4)$ & $3.0(2-4)$ & $3.0(2-4)$ & $<0.0001$ \\
\hline & 1 & $285 / 1,662(17.1 \%)$ & $17 / 82(20.7 \%)$ & $198 / 1,108(17.9 \%)$ & $70 / 472(14.8 \%)$ & 0.0001 \\
\hline & 2 & $426 / 1,662(25.6 \%)$ & $24 / 82(29.3 \%)$ & $310 / 1,108(28.0 \%)$ & $92 / 472(19.5 \%)$ & \\
\hline & $\geq 3$ & $951 / 1,662(57.2 \%)$ & $41 / 82(50.0 \%)$ & $600 / 1,108(54.2 \%)$ & $310 / 472(65.7 \%)$ & \\
\hline $\begin{array}{l}\text { Gestational age, } \\
\text { weeks }\end{array}$ & Mean \pm SE & $39.0 \pm 0.08$ & $38.4 \pm 0.3$ & $39.3 \pm 0.1$ & $38.4 \pm 0.2$ & $<0.0001$ \\
\hline Hemoglobin, g/dL & Mean \pm SE & $10.1 \pm 0.03$ & $10.3 \pm 0.2$ & $10.2 \pm 0.04$ & $9.8 \pm 0.1$ & $<0.0001$ \\
\hline \multirow[t]{4}{*}{ Hemoglobin level } & $<7$ & $32 / 1,645(1.9 \%)$ & $2 / 81(2.5 \%)$ & $19 / 1,097(1.7 \%)$ & $11 / 467(2.4 \%)$ & $<0.0001$ \\
\hline & $7-8.5$ & $158 / 1,645(9.6 \%)$ & $6 / 81(7.4 \%)$ & $91 / 1,097(8.3 \%)$ & $61 / 467(13.1 \%)$ & \\
\hline & $8.5-11$ & $1,015 / 1,645(61.7 \%)$ & $47 / 81(58.0 \%)$ & $662 / 1,097(60.3 \%)$ & $306 / 467(65.5 \%)$ & \\
\hline & $\geq 11$ & $440 / 1,645(26.7 \%)$ & $26 / 81(32.1 \%)$ & $325 / 1,097(29.6 \%)$ & $89 / 467(19.1 \%)$ & \\
\hline Mean BMI, $\mathrm{kg} / \mathrm{m}^{2}$ & Mean \pm SE & $23.3 \pm 0.08$ & $23.0 \pm 0.31$ & $23.6 \pm 0.1$ & $22.5 \pm 0.1$ & $<0.0001$ \\
\hline \multirow[t]{4}{*}{ BMI, $\mathrm{kg} / \mathrm{m}^{2}$} & $<18.5$ & $44 / 1,662(2.6 \%)$ & $0 / 82(0.0 \%)$ & $24 / 1,108(2.2 \%)$ & $20 / 472(4.2 \%)$ & $<0.0001$ \\
\hline & $18.5-25$ & $1,233 / 1,662(74.2 \%)$ & $68 / 82(82.9 \%)$ & $791 / 1,108(71.4 \%)$ & $374 / 472(79.2 \%)$ & $<0.0001$ \\
\hline & $25-30$ & $328 / 1,662(19.7 \%)$ & $12 / 82(14.6 \%)$ & $244 / 1,108(22.0 \%)$ & $72 / 472(15.3 \%)$ & \\
\hline & $\geq 30$ & $57 / 1,662(3.4 \%)$ & $2 / 82(2.4 \%)$ & $49 / 1,108(4.4 \%)$ & $6 / 472(1.3 \%)$ & \\
\hline \multirow[t]{4}{*}{$\begin{array}{l}\text { CD4+ cell counts, } \\
\text { cells } / \mu \mathrm{L}\end{array}$} & Mean \pm SE & $376 \pm 7$ & $362 \pm 23$ & $414 \pm 7$ & $287 \pm 9$ & $<0.0001$ \\
\hline & $<200$ & $339 / 1,493(22.7 \%)$ & $20 / 73(27.4 \%)$ & $161 / 998(16.1 \%)$ & $158 / 422(37.4 \%)$ & $<0.0001$ \\
\hline & $200-349$ & $434 / 1,493(29.1 \%)$ & $16 / 73(21.9 \%)$ & $281 / 998(28.2 \%)$ & $137 / 442(32.5 \%)$ & \\
\hline & $\geq 350$ & $720 / 1,493(48.2 \%)$ & $37 / 73(50.7 \%)$ & $556 / 998(48.1 \%)$ & $127 / 422(30.1 \%)$ & \\
\hline \multirow[t]{2}{*}{$\begin{array}{l}\text { Preterm birth, }<37 \\
\quad \text { weeks }\end{array}$} & Yes & $1,293 / 1,662(77.8 \%)$ & $58 / 82(70.7 \%)$ & 204/1,108 (18.4\%) & $141 / 472(29.9 \%)$ & $<0.0001$ \\
\hline & No & $369 / 1,662(22.2 \%)$ & $24 / 82(29.3 \%)$ & $904 / 1,108(81.6 \%)$ & $331 / 472(70.1 \%)$ & \\
\hline Birth weight, ${ }^{*}$ grams & Mean \pm SE & $2,975 \pm 13$ & $2,854 \pm 64$ & $3,037 \pm 14.5$ & $2,850 \pm 27$ & $<0.0001$ \\
\hline \multirow[t]{2}{*}{ Low birth weight ${ }^{*}$} & Yes & $209 / 1,659(12.6 \%)$ & $18 / 82(22.0 \%)$ & $104 / 1,105(9.4 \%)$ & $87 / 472(18.4 \%)$ & 0.0001 \\
\hline & No & $1,450 / 1,659(87.4 \%)$ & $64 / 82(78.0 \%)$ & $1,001 / 1,105(90.6 \%)$ & $385 / 472(81.6 \%)$ & \\
\hline \multirow[t]{2}{*}{ Newborn sex } & Male & $844 / 1,661(50.8 \%)$ & $40 / 81(49.4 \%)$ & $583 / 1,108(52.6 \%)$ & $221 / 472(46.8 \%)$ & 0.03 \\
\hline & Female & $817 / 1,661(49.2 \%)$ & $41 / 81(50.6 \%)$ & $525 / 1,108(47.4 \%)$ & $251 / 472(53.2 \%)$ & \\
\hline
\end{tabular}

Q $\mathrm{Q} 1$ = first quartile; Q3 = third quartile; BMI = body mass index.

${ }^{\dagger}$ Chi-square test compared the last two columns of higher viral load with lower viral load, and the respective $P$ values are presented. 
Table 4

Multivariate analyses of placental malaria and adjusted odds ratios of human immunodeficiency virus-1 infection status in the newborn*

\begin{tabular}{|c|c|c|c|c|c|c|}
\hline Factor & $\begin{array}{c}\text { Unadjusted } \\
\text { OR }\end{array}$ & $95 \% \mathrm{CI}$ & $P$ & $\begin{array}{l}\text { Adjusted } \\
\text { OR }\end{array}$ & $95 \% \mathrm{CI}$ & $P$ \\
\hline \multicolumn{7}{|c|}{ Placental malaria } \\
\hline Yes & 1.17 & $0.57-2.37$ & 0.67 & 1.06 & $0.51-2.20$ & 0.87 \\
\hline No & 1.00 & - & & 1.00 & - & \\
\hline \multicolumn{7}{|c|}{ CD4+ cell counts, cells $/ \mu \mathrm{L}$} \\
\hline$<200$ & 2.33 & $1.50-3.63$ & $<0.001$ & 1.64 & $1.03-2.60$ & 0.04 \\
\hline $200-350$ & 1.08 & $0.66-1.76$ & 0.77 & 0.96 & $0.59-1.57$ & 0.88 \\
\hline$\geq 350$ & 1.00 & - & & 1.00 & - & \\
\hline \multicolumn{7}{|c|}{ Plasma viral load, copies/mL } \\
\hline$\geq 55,000$ & 2.78 & $1.92-4.04$ & $<0.001$ & 2.31 & $1.55-3.44$ & $<0.001$ \\
\hline$<55,000$ & 1.00 & - & & 1.00 & - & \\
\hline
\end{tabular}

Multivariate models adjusted for plasma viral load, CD4+ cell counts, trichomoniasis, bacterial vaginosis, preterm birth, low birth weight, and randomization arm. $\mathrm{OR}=$ odds ratio $; \mathrm{CI}=$ confidence interval. 
Table 5

Multivariate analyses of placental malaria and adjusted odds ratios of human immunodeficiency virus-1 infection status in the newborn within strata of baseline maternal plasma viral load*

\begin{tabular}{lccccccc}
\hline Factor & $\begin{array}{c}\text { Unadjusted } \\
\text { OR }\end{array}$ & $\mathbf{9 5 \%} \mathbf{C I}$ & $\boldsymbol{P}$ & $\begin{array}{c}\text { Adjusted } \\
\text { OR }\end{array}$ & $\mathbf{9 5 \%} \mathbf{C I}$ & $\boldsymbol{P}$ & $\begin{array}{c}\boldsymbol{P} \text { for } \\
\text { interaction }\end{array}$ \\
\hline $\begin{array}{c}\text { Placental } \\
\text { malaria }\end{array}$ & & & & & & & 0.08 \\
$\begin{array}{c}\text { Viral load } \\
\quad<55,000 \\
\text { copies/mL }\end{array}$ & 2.08 & $0.86-5.06$ & 0.106 & 1.99 & $0.81-4.90$ & 0.14 & \\
$\begin{array}{c}\text { Viral load } \\
\quad 55,000 \\
\text { copies/mL }\end{array}$ & 0.47 & $0.14-1.55$ & 0.213 & 0.51 & $0.15-1.74$ & 0.28 \\
\hline
\end{tabular}

Multivariate model adjusted for CD4+ cell counts, plasma viral load, trichomoniasis, bacterial vaginosis, preterm birth, low birth weight, and randomization arm. $\mathrm{OR}=$ odds ratio; $\mathrm{CI}=$ confidence interval. 